at the same level as the human skeleton has not been identified with any recent or extinct species ; likewise that the depth in the mud or loam (five feet thick in all) in which the skeleton was found has not been recorded.

A priori probability would lead biologists to infer that pithecoid man first existed on this planet; but in the present stage of the controversy it is, in my opinion, most hazardous to frame a table on the mere probability of a fact.

Yours very truly,

C. Carter Blake.

\title{
The Portland Fissures with Human Remains.
}

Sir,-Will you allow me to make some remarks on the letter of $\mathrm{Mr}$. Jicks in the 'Geologist' of this month, in which he seems to doubt the correctness of the facts which I mentioned in my letter in the 'Geologist' of last month, that the remains of man and of extinct mammalia have been found mingled together in fissures of the rock of Portland Island, which fissures do not extend to the surface of the rock?

The whole question depends, of course, on the nature of evidence which I produced of the truth of these facts. My first evidence was the testimony of the writer of an article in 'Willis's Current Notes' for the month of August, 1852, who had himself visited Captain Manning, at Portland Castle. He states expressly - on the authority, of course, of Captain Manning-that on several of the ledges, in the fissures of the Portland rock, which do not extend to the surface-soil by 5 or 10 feet, a number of bones of all kinds of animals have been found, including those of the human species. The truth of this statement has been in the fullest manner confirmed to me by Captain Manning himself, who showed me, at the Castle, his collection of bones, which were those of men, the elk, the reindeer, the elephant, etc. He said that the fissures in which they were found did not extend to the surface of the rock. He also said, what is stated in 'Willis's Current Notes,' that Dr. Buckland, who visited him at the Castle, being first attracted to the island by the discovery of a fossil boar's head, having doubts as to the place where the bones were found, accompanied him to the fissure, where a lad was let down, who brought up more of the bones in his presence.

The next evidence which I produced was an article in the "Times' of the lst of last January, relating to the fortifications recently built in Portland Island. 'The article states that in these fissures, "commencing about 20 feet below the surface of the ground, human bones have been found with those of wild boars, and horns of reindeer, not fossilized, but with all their osseous structure as perfect as if they were not fifty years old." The high preservation of these bones proves that they must have remained entirely excluded from the air from the time that they entered the limestone formation to the period of their discovery.

Can the facts which I have mentioned be disproved,-that human and mammalian bones have been found in fissures of the Portland rock, which do not extend to the surface of the rock? If these facts are true, which may be easily ascertained by any person's visiting the island, they prove, beyond a doubt, that the human and mammalian bones must have been embedded in the rock before its consolidation, and consequently, that the men and animals to whom they belonged must have inhabited some other dry land, probably now destroyed.

Again, what can explain the association in the fissures of the bones of the reindeer, an arctic animal, with those of a tropical animal, the elephant,

VOL. VI. 
but that they were brought to the same spot from arctic and tropical regions by the catastrophe which buried them in the Oolite formation, which was probably a universal deluge? For arctic and tropical animals never could have lived together in the same climate. 'The association of the remains of arctic and tropical animals has also been observed in other places. In a cavern at Brixham, near Torquay, in a mass of loam or diluvium, 15 feet in thickness, have been found the remains of the mammoth, the extinct rhinoceros, cave-lion, cave-bear, cave-hyæna, reindeer, a species of horse, of ox, and several Rodentia, besides other bones not yet determined. Speaking of similar geological facts, M. Cuvier remarks, that " the associated remains of the glutton and the hyæna, the rhinoceros and the reindeer, found in the same caverns, as we observe at Gaylenreuth and Brengues; the bison and the elephant, in the same dilavium, as we find in the valley of the Arno, - certainly reveal either a state of the earth very different from what we now witness, or imply in these animals a temperament opposite to what their kindred species now display." The remains of the lion or tiger, the rhinoceros, the hyæna, elephant, elk and reindeer, and other animals, have also been found in the quarries of Kostritz, in Upper Saxony.

As the remains of arctic and tropical animals, whether found in caverns or on the surface of the earth, are almost always embedded in loam or diluvium, which, according to Dr. Buckland, was deposited by a general deluge, it is far more reasonable to suppose that, as I have already intimated, they were transported to their present situations by a general deluge than that amimals belonging now to such opposite climates should have formerly lived together in the same elimate.

I am, Sir, your obedient servant, Trros. D. Aluen.

\section{Rectory, North Cerney, Cirencester, Aprit 21, 1863.}

[How could there be a fissure before the rock was consolidated? and are we to believe that the elephants, etc., and men too, in those days, lived at the bottom of the sea, as they must be supposed to have done if we accept Mr. Allen's theory of the Portland ossiferous fissures occurring before the consolidation of the Portland Oolitie beds? Fissures of shrinkage may not, sometimes do not, extend to the top of a vertical section, any more than sand-pipes in a chalk-pit, which we know to be filled from above. The accompanying diagrams will show how a fissure may extend to the surface, and yet not be visible, in the face of a quarry or cliff occurs at Portland, and no doubt something of this kind has mystified Mr. Allen and his friends. -ED. GEOL.]

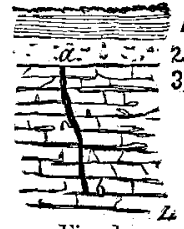

Fig. 1 .

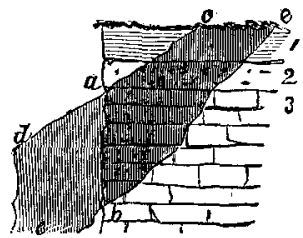

Fig. 2 .

Fig. 1 shows the vertical face of the quarry, with a fissure, $a b$, apparently covered by the solid beds 1,2. Fig. 2 shows the same fissure in section passing diagonally through the beds to the surface.

\section{Human Remains at Luton.}

Sre,-With respect to my letter of last month announcing the discovery of two human skeletons in the brick-earth at Luton, subsequent careful 